\title{
Efficacy of Separate and Premix Formulation of Metsulfuron-Methyl and Carfentrazone-Ethyl on Weeds in Wheat: A Review
}

\author{
Ajit Kumar Paswan ${ }^{1}$, Devendra Mandal ${ }^{2}$, Narendra Kumawat ${ }^{3}$, Jeetendra Kumar ${ }^{1}$, \\ Rakesh Kumar ${ }^{4 *}$, Anil Kumar Singh ${ }^{4}$ and Anil Kumar ${ }^{5}$ \\ ${ }^{1}$ Krishi Vigyan Kendra, Jehanabad, BAU, Sabour-Bihar, India \\ ${ }^{2}$ Krishi Vigyan Kendra, Rohtas, BAU, Sabour-Bihar, India \\ ${ }^{3}$ AICRP on Maize-Zonal Agricultural Research Station, Jhabua-457 661, MP, India \\ ${ }^{4}$ ICAR-Research Complex for Eastern Region, Patna-797 106, Bihar, India \\ ${ }^{5}$ Zonal Research Station, Chianki, Palamau, BAU, Kanke-834 006, India \\ *Corresponding author
}

\section{A B S T R A C T}

India has a wide range of agro-climates regions and soil types. The highly diverse

Keywords

Herbicides,

Weed, Wheat,

Weed control

efficiency, Yield.

Article Info

Accepted:

23 June 2017

Available Online:

10 July 2017 agriculture systems are beset with different types of weed problem. Weeds cause 10$80 \%$ crop yield losses besides deteriorating quality of products and causing health and environmental hazards. Traditionally, weed control has been largely dependent on manual weeding. However, increased labour scarcity and costs are encouraging farmers to adopting labour and cost saving options. Research on weed management in India is mostly centered on herbicide efficacy. Herbicides applied alone or in combination, have been regarded as essential tools in effective management of weeds in different ecosystem. To meet the demands of increasing population and avoid food import, crop productivity in India needs major improvement, which can be attained by identifying the constraints that hinder in achieving higher yields of wheat. Detailed review of weed flora and weed shift, factor of weed competition and management' options future in India is made under this chapter.

\section{Introduction}

Wheat is an important crop in worldwide and in India, its production increased from a mere 11 MT during 1960-61 to 97.4 MT during 2016-17 (Singh et al., 2017a). This more than 8-fold increase in wheat production was mainly due to adoption of short stature HYVs, use of fertilizers, irrigation and herbicides (Singh et al., 2017b). High nutrient and water requirement along with less competitive nature of these HYVs have provided conducive environment for increased weed infestation. Weeds are regarded as most the disdain to crop production and account for $\sim 1 / 3^{\text {rd }}$ of total losses caused by all pests (Chhokar et al., 2012).

Weeds have a direct impact on crop productivity including costs of labour, equipment, chemical and other management input (Singh et al., 2011a). Weeds also impact 
wheat production indirectly by competing with crop for resources, harbouring crop pest, interfering with water management, reducing grain yield, quality and increasing cost of processing (Zimdahl, 2013). Major weeds associated with wheat are Phalaris minor, Avena spp., Chenopodium album, Melilotus spp., Anagallis arvensis, Vicia sativa, Lathyrus aphaca and Rumex dentatus. In recent years, a new species Rumex sp. has emerged as serious problem in irrigated wheat eco-system (Singh et al., 2011b). Therefore, complexity and diversity of weed flora require more than one herbicide either in sequence or as mixture.

Low wheat productivity is due to delayed and sub-optimal wheat establishment, which is further due to late harvesting of long duration rice varieties and weed infestation (Maurya $e t$ al., 2013 and Singh et al., 2014). Continuous application of a similar herbicide or use of lower than recommended dose led to development of herbicide resistance (Yadav et $a l ., 2013)$. The weed flora of wheat consists of both grassy and broad leaf weeds and if uncontrolled; they interfere crop growth by competing for available nutrient, light and water (Jeet et al., 2010a, b, c). Consequently such competition depends upon type of weed species, severity of weed infestation and climatic condition, which affects weed and crop growth (Rao, 2000). In India it has been estimated that out of total yield losses caused by the pests in wheat, weeds account $\sim 33 \%$ and extent of yield reduction largely depends on growth and behavior of individual weed species in relation to agro-ecological condition. Eradication of weeds from crop is essential for obtaining the maximum returns. Various methods for eradication of weeds are hoeing, weeding, dabbing, tillage, harrowing, crop rotation biological and chemical control. Therefore, for sustaining food-grain production to feed ever-increasing population, ensuring food security, effective weed management is very essential.

\section{Weed flora and weed flora shift}

Weed floras associated with wheat have been found variable in different agro-ecological regions of the country (Table 1 ). In general, Phalaris minor Retz., Avena spp., Chenopodium album, Melilotus spp., Cyperus rotundus and Cynodon dactylon have been observed in most wheat growing areas of India (Singh and Ghosh, 1992). A survey of wheat fields were conducted on farmers' fields in Eastern Indo-Gangetic region, Faizabad and revealed that crop was infested with Phalaris minor, Anagallis arvensis, Cyperus rotundus, Lathyrus aphaca, Chenopodium album, Vicia sativa and Avena ludoviciana (Vaishya and Kumar, 1993). Singh et al., (1997) observed relative composition of weed flora as Melliotus spp. (24.2\%), Anagallis arvensis (20.7\%), Phalaris minor (18\%) Chenopodium album (13.8\%), Cyperus rotundus (11.1\%) and Cynodon dactylon $(8.3 \%)$ in wheat. Sidhu et al., (2000) reported Rumex spinosus a hardy broad leaf weed, becoming very serious problem in several wheat growing areas of Punjab. In other instance, Sardana et al., (2001) observed heavy infestation $(73.4 \%)$ of Medicago denticulate in wheat field at Gurdaspur, Punjab. Malik et al., (2001) reported infestation of Avena ludoviciana, Chenopodium album, Phalaris minor, Melilotus indica, Fumaria parviflora and Convolvulus arvensis in wheat crop at Hisar, Haryana, India. Thirteen weed spp. were found infesting wheat fields and of these Phalaris minor, Polygonum monospeliensis, Poa annua, Rumex aspera, Medicago denticulata, Anagallis arvensis, Lepidium sativa and Malva neglecta were the most common. Relative frequency, relative density, important value and dominance ratio of Phalaris minor has highest among different weed species (Brar and Walia, 2007). Jat et al., (2007) found that major grassy weed of wheat are Phalaris minor Retz.(29.7\%), 
Avena ludoviciana L. (40.1\%), whereas BLWs are Lathyrus aphaca L. (8.8\%), Chenopodium album L. (8.2\%), Melilotus indica L. (4\%), Rumex retroflexus L. (4.0\%), Coronopus didymus L. (2.7\%), Circium arvensis L.(2.5\%). Garg et al., (2007) reported that Phalaris minor was the dominant weed $(49 \%$ of the total weed density), followed by Chenopodium album, Rumex retroflexus, Anagallis arvensis, Chenopodium murale, Melilotus indica and Coronopus didymus in 31 wheat fields in Panipat district, Haryana, India. Malva parviflora infested $96 \%$ of the wheat fields (25.6 plants $/ \mathrm{m}^{2}$ ) Avena ludoviciana [Avena sterilis sub sp. ludoviciana], which was the dominant weeds. Poa annua, Anagallis arvensis and $R$. retroflexus infested 6.4, 93.5 and $100 \%$, respectively. Vashisht et al., (2008) observed wheat infestation of 23 weed species comprising 14 families of grasses, sedges and BLWs. Phalaris minor, Avena ludoviciana [A. sterilis sub sp. ludoviciana], Vicia sativa, Rumex sp. and Lathyrus aphaca were the pre-dominant weeds of rice-wheat sequence, whereas $P$. minor, A. ludoviciana, Chenopodium album, Asphodelus tenuifolius and Cirsium arvense were the pre-dominant weeds of bajra-wheat and arhar-wheat sequences. Five major weeds with $100 \%$ event were $P$. minor, A. ludoviciana, $V$. sativa, L. aphaca and M. indica.

\section{Factors of crop weed competition}

Weeds compete with crop plant for moisture, nutrients, light and space, thereby depriving crop of vital input. Therefore, weed competition is one of the most important constraints in crop production. Weed-crop competition begins, when crop plants and weeds grow in close proximity and their root or shoot system overlap. The competition becomes severe due to more smothering effect, when weeds emerge earlier than the crop. In rice-wheat system, due to enough soil moisture after harvesting of rice, weeds emerge earlier than wheat. Losses in wheat yield are primarily due to reduction in tillering. Under ample soil water and plentiful nutrient supply condition light become the prime factor around which competition forces developed when two grasses grow in association at a nitrogen supply level the yield is limited by light. Cudeny et al., (1991) observed that Avena fatua grew taller than wheat having plant height of 87 to $72 \mathrm{~cm}$, respectively at anthesis under non limiting nitrogen and moisture condition and had a greater portion of their canopy above $80 \mathrm{~cm}$ at maturity (28 to 35 and $11.16 \%$, respectively). Water is an essential factor for growth and development of crop plants. Wheat being post-monsoon crop, suffers from water scarcity due to presence of competing weeds if not managed. Competition between cereal crop and weed is primarily for $\mathrm{N}$ in early stage of crop growth and if weed is allowed to grow the growth and yield of crop adversely affected. Gautam et al., (1975) from their studies on herbicide and interaction noted a loss of $40.5 \mathrm{~kg} \mathrm{~N} / \mathrm{ha}$ in wheat due to weed competition. Weed control treatment increased the $\mathrm{N}, \mathrm{P}$ and $\mathrm{K}$ uptake in crop $135.5,149.0 \%$ and $148.6 \%$ compared to weedy check, respectively. Pandey and Singh (1983) observed when associated weeds were allowed to compete with the wheat crop up to harvest, they depleted 9.6, 1.13 and $5.12 \mathrm{~kg}$ of $\mathrm{N}, \mathrm{P}$ and $\mathrm{K}_{2} \mathrm{O} /$ ha, respectively. Kundra and Singh (1985) found that quantity of $\mathrm{N}$ depletion by weed increased with advanced growth stage due to increased efficiency of applied herbicides and sugarcane of new flushes of weed resulting in increased weed dry matter production. Pandey et al., (2000) summarized that an increasing fertilizer levels resulted significantly better crop performance along with higher weed count and weed dry weight then no fertilizer in wheat. Competition among plants depends on morphology differential response to 
environmental parameters ability to extract nutrients and water from rain and other factors. Aldrich (1987) reported that reduction of yield includes environmental condition, time of emergence and possible allelopathic influence. Sage et al., (1987) reported Chenopodium album was more productive at low nitrogen level and had greater nitrogen use efficiency than weeds like Amaranthus retroflexus. Martin and Field (1988) observed that emergence of wild oat 21 DAS did not affect yield of wheat such as simultaneous emergence of weed seed with wheat seedling. The critical period of weed control in wheat is 30-45 DAS and crop should be kept weed free during this period. Majority of farmers are not adhering to this critical period for management of weeds and they mostly delay the herbicide application.

\section{Effect of weeds on crop growth and yield}

Weed competitive efficiency in cereal crops depends more on root development, time of germination or development of large assimilation surface. Most of weeds had larger root systems and greater assimilation surface than cereals. Singh and Tondon (1966) reported yield reduction in wheat by individual of weed i.e. Chenopodium album and Alium tennuifolius were 25 and 13\%, respectively. Nalawaja (1968) reported that densities of Avena fatua 70 and 160 yard $^{-2}$ reduced wheat yield 20 and $39 \%$, respectively compared to a weed free control. Gautum et al., (1975) observed 60\% wheat yield loss to unchecked weed growth. Reeves (1976) observed that number of fertile spikelets and dry matter production of wheat crop was reduced by presence of rye grass in wheat crop. Weed compete with crop plants for nutrients and other growth factors and in the absence of an effective control measure, remove considerable quantity of applied nutrients and decreased yield to a significant level. Tosh and Mishra (1977) observed that grain yield of wheat was reduced by $66.7 \%$ due to the presence of Digitaria sanguinalis, Phalaris minor, Eleusine indica, Acanthosperum trispidum and Euphatorium glandulosum. Jalis and Brohi (1978) observed presence of weeds significantly reduced number and size of ears in wheat crop. Thomas and Yaduraju (1999) reported that increasing wild oat density from 0 to $288 \mathrm{~m}^{-2}$ reduced leaf area of wheat at 60 DAS by 33$41 \%$ and at 90 DAS by $60-72 \%$ and dry matter production in range of 47-55 and 35$48 \%$ at 60 DAS and $69-73 \%$ at 90 DAS. Godel (1995) studies the effect of normal annual infestation of weeds on wheat and observed significant difference in number of tillers, length of ear weight of kernels and yield of crop due to weedy conditions. Verma and Pandey (2002) found weed competition results lowered crop yield by $27.2 \%$. Verma and Pandey (2004) observed competition effect of wheat with canary grass, wild oat, blue pimpernel and lamb and reported crop yield loss up to $35 \%$.

\section{Effect of herbicide mixture on crop growth and yield}

Chemical weed control method is preferred over other weed control methods because it is quick, more effective and relatively cheaper. Inorganic salts, copper sulphate, were used for controlling broad leaved weeds in cereals towards end of $19^{\text {th }}$ century. Extensive use of relatively low dose (1-2 kg/ha) began with the launch of growth regulation herbicides MCPA. The success of these herbicides led to development and production of new herbicide groups and compound have their efficacy in minimizing weed menace in most crop including wheat. Today herbicides constitute integral part of weed management in crops for producing high economic yield. Further, increased use of herbicides can be attributed to increasing labour wages, unavailability of labours at critical period of weeding and to a 
great extent infestation of weeds not easily distinguished from crop at early stages of growth (Yadav et al., 2013).

\section{2, 4-D}

The discipline of weed science began about 1945 with the introduction of selective, synthetic herbicides, beginning with 2, 4-D. The growing need for research to study the efficacy, mode of action, environmental effects, application technology, and other aspects of this herbicide led to extensive study in different parts of world. In India, since introduction of 2, 4-D as a herbicide has been widely used for the control of broad leaf weeds. Singh (1967) observed that 2,4-D sodium salt at $1.0 \mathrm{~kg}$ a.i./ha applied as preemergence and repeated post-emergence gave the best control of weeds and produced the highest yield of grain (34.1q/ha). Mishra and Mani (1968) recommended one spraying of 2, 4-D at $0.42 \mathrm{~kg} / \mathrm{ha}$ applied $30 \mathrm{DAS}$ for effective control of weeds and higher yield of tall wheat. Singh and Singh (1979) noted on increase of $24.6 \%$ in wheat grain yield due to application of 2,4-D ester salt. Nayak et al., (2003) revealed that all the weed control treatments significantly decreased the dry weight of weeds at harvest of crop compared to weedy control. Among the herbicidal treatments 2, 4-D and metsulfuron-mthyl alone and their combinations showed their superiority over isoproturon alone and combination of isoproturon with metsulfuronmethyl. Grain yield of wheat was recorded the highest with hand weeding followed by combined application of 2, 4-D and metsulfuron-methyl at $500 \mathrm{~g} / \mathrm{ha}$ and 2 or 4 g/ha, respectively. Singh et al., (2013) found that metsulfuron+2,4-D @ 6g and 500g/ha was most effective herbicide for controlling of both type of weed flora i.e narrow and BLWs throughout the growing season in wheat. Similarly, maximum yield was achieved with the application of metsufuron
$+2,4-\mathrm{D}$, and increase in grain yield of wheat crop owing to better control of weeds.

\section{Carfentrazone-ethyl}

Carfentrazone-ethyl belongs to aryl triazolinone family, which has been found effective to control BLWs in wheat by inhibiting activity of protoporphyrinogen oxidase in chlorophyll biosynthetic pathway was evaluated against these weeds and compared with existing recommended herbicides in wheat (Witkowsski and Halling, 1989). Recently, carfentrazone has been recommended for BLWs control and added advantage with this herbicide is that it has very fast action and control Malva spp and Solanum nigrum. Singh et al., (2004) reported that Carfentrazone had better efficacy than 2, 4-D and was comparable with metsulfuron. The grain yields recorded in wheat treated with carfentrazone-ethyl and metsulfuronmethyl were similar to weed-free control. The total weed dry matter production in 2, 4-D treated plots was higher than that of carfentrazone-ethyl. Patel et al., (2005) conducted field study at Anand, Gujarat and reported that Carfentrazone-ethyl at $20 \mathrm{~g} / \mathrm{ha}$ recorded comparable yield to 2, 4-D at recommended rate. Punia et al., (2006) reported that post-emergence application of Carfentrazone at $20 \mathrm{~g} /$ ha provided (92-100) $\%$ control of all broadleaf weeds including hard controlling weeds Malwa parviflora and convolvulus arvensis in wheat with no residual effect on succeeding sorghum crop. Chopra et al., (2008) reported that carfentrazone $20 \mathrm{~g} / \mathrm{ha}$ and metsulfuron $4 \mathrm{~g} / \mathrm{ha}$ controlled 83.7 and $84.1 \%$ of broadleaf weeds-respectively and increased seed yield significantly. Carfentrazone at 10 and $20 \mathrm{~g} / \mathrm{ha}$ and metsufuron $4 \mathrm{~g} / \mathrm{ha}$ did not cause any adverse effect on seed germination and vigour hence can be used in seed production plots of wheat. 


\section{Carfentrazone ethyl+other herbicide} (mixture)

Chopra and Chopra (2005) observed that tank mixture of clodinafop $(60 \mathrm{~g} / \mathrm{ha})$ with carfentrazone $(20 \mathrm{~g} / \mathrm{ha})$ controlled both grassy and BLWs resulting 88-90\% weed control efficiency and significantly increase seed yield of wheat over sole application of clodinafop and fenoxaprop, tank mixture of metribuzin and isoproturon with carfentrazone and metsulfuron.Singh and Singh (2005) found clodinafop-propargyl was compatible with metsulfuron-methyl [metsulfuron] and carfentrazone-ethyl [carfentrazone] (tank mixture) with regard to the control of Phalaris minor and Chenopodium album in wheat. Fenoxaprop-Pethyl was compatible with carfentrazone-ethyl but not with metsulfuron-methyl. Similarly, post-emergence (35-40 DAS) application of triasulfuron at $15 \mathrm{~g} / \mathrm{ha}$ (with and without $1 \%$ surfactant) and $20 \mathrm{~g} / \mathrm{ha}$ alone as well as carfentrazone-ethyl 20 and $25 \mathrm{~g} / \mathrm{ha}$ controlled BLWs in wheat very effectively and produced grain yield at par with the already recommended herbicide i.e. 2, 4-D $0.5 \mathrm{~kg} / \mathrm{ha}$ (Walia and Singh, 2007). Chopra et al., (2008) studied the effect of different herbicides as sole and their tank mixtures on wheat (Triticum aestivum) and reported that highest grain yield of $4.49 \mathrm{t} / \mathrm{ha}$ was recorded with fenoxaprop- $p$-ethyl + carfentrazone $(100+10 \mathrm{~g} / \mathrm{ha})$ applied 30 days after sowing, which was at par with weed-free treatment. Although tank mixture of isoproturon + carfentrazone showed greater control of BLWs, it gave significantly lower control of grassy weed (Phalaris minor) compared with fenoxaprop- $p$-ethyl + carfentrazone. Metsulfuron alone at 4 and $8 \mathrm{~g} / \mathrm{ha}$ was superior to 2, 4-D and carfentrazone $10 \mathrm{~g} / \mathrm{ha}$ for dry weight of weeds and weed control efficiency. There was a reduction of $25.7 \%$ in the seed yield under weedy control conditions. Yadav et al., (2009) evaluated the compatibility of fenoxaprop-P-ethyl with carfentrazone-ethyl for the control of complex weed flora in wheat. Among all the treatments, maximum number of effective tillers and grain yield were recorded with fenoxaprop + carfentrazone $120 \mathrm{~g} / \mathrm{ha}(5: 1)$. Carfentrazone was compatible with fenoxaprop as tank mixture and there was no adverse effect on efficacy of both the herbicides. Fenoxaprop + carfentrazone 120 $\mathrm{g} / \mathrm{ha}(5: 1)$ appeared to be best combination for achieving maximum WCE (\%) and improved grain yield. Metsulfuron 2, 4-D Ester and $\mathrm{Na}$ salt had antagonistic effect on efficacy of fenoxaprop when applied as tank mixture with it. Mustari et al., (2014) reported carfentrazone-ethyl + Isoproteuron contributed to the highest grain yield.

\section{Metsulfuron-methyl}

Sharma and Ahuja (2001) evaluated bioefficacy of chlorsulfuron, metsulfuron-methyl and metribuzin and reported yield obtained with the application of chlorsulfuron at 30 $\mathrm{g} / \mathrm{ha}$, metsulfuron-methyl at $8 \mathrm{~g} / \mathrm{ha}$ and alone and combine application of chlorsulfuron at $15 \mathrm{~g} / \mathrm{ha}$ and Metribuzin at 100 and $200 \mathrm{~g} / \mathrm{ha}$ were statistically similar to weed free. Similarly, Singh and Ali (2004) assessed efficacy of metsulfuron-methyl against Chenopodium album, Chenopodium murale, Lathyrus aphaca, Melilotus alba, Rumex dentatus, Convolvulas arvensis, Vicia hirsute, Medicago denticulate, Avena ludoviciana [Avena sterilis sub sp. Ludoviciana], Cynodon dactylon and Cyperus rotundus in wheat and its residual effects on succeeding soybean crop. Results reveled application of metsulfuron-methyl was very effective against the broad leaved weeds and did not have any residual effect on succeeding soybean crop. Metsulfuron-methyl $4 \mathrm{~g} / \mathrm{ha}$ was most effective in controlling BLWs and was greater than 2,4-D and farmers' practice in increasing wheat yield. Hooda et al., 
(2007) reported that all the yield attributes remained statistically at par with each other in plots treated with various doses of metsulfuron-methyl $(2,4$ and $8 \mathrm{~g} / \mathrm{ha})$. However, among different doses of metsulfuron-methyl, $\quad 8.0 \mathrm{~g} / \mathrm{ha}$ recorded maximum value for yield attributes. Among the plots treated with metsulfuron-methyl, these differences were, however, non significant because wheat might have metabolized herbicide with time. Nayak et al., (2003) also reported similar results. Malik et al., (2008) reported chlorsulfuron $30 \mathrm{~g} / \mathrm{ha}$, metsulfuron $4 \mathrm{~g} / \mathrm{ha}$ and triasulfuron $60 \mathrm{~g} / \mathrm{ha}$ reduced density of different BLWs in wheat to the extent of $90-100 \%$ and proved better than sulfosulfuron (20 and $25 \mathrm{~g} / \mathrm{ha}$ ) and 2, 4D Na salt (500 and $750 \mathrm{~g} / \mathrm{ha}$ ). Chopra and Chopra (2010) reported sequential or tank mixture application of fenoxaprop (100 g/ha) and clodinafop $(60 \mathrm{~g} / \mathrm{ha})$ with metsulfuron at $4 \mathrm{~g}$ a.i. /ha were more effective than their individual application.

\section{Metsulfuron-methyl + other herbicide (mixture)}

Advantage of combination of metsulfuron and carfentrazone over alone application of metsulfuron and carfentrazone will be in situations having the diverse infestation BLWs particularly $M$. parviflora, S. nigrum and L. aphaca. Ready mix combination of metsulfuron + carfentrazone will provide the control of these weeds. Kurchania et al., (2000) revealed that the higher grain yield of wheat was obtained with the application of metsulfuron-methyl at 4 g/ha+2,4-D @ 500 $\mathrm{g} / \mathrm{ha}$ or metsulfuron-methyl at $4 \mathrm{~g} / \mathrm{ha}+2,4-\mathrm{D}$ at $250 \mathrm{~g} / \mathrm{ha}$ and HW under weedy control. However, yield differences amongst metsulfuron-methyl at 2 and $4 \mathrm{~g} / \mathrm{ha}$ either alone or in mixed application with, 2, 4-D was not significant. Pandey et al., (2000) reported that effect of Metsulfuron methyl, 2, 4-D and their tank mix on weeds. All the weed control treatments significantly decreased weed dry matter production, where in the combined application of metsulfuron methyl+2, 4-D was lower than 2, 4-D alone and Isoproturon. Combined application of $4 \mathrm{~g}$ Metsulfuron-methyl/ha and $500 \mathrm{~g} \mathrm{2,4-D} \mathrm{Na}$ salt/ha had the highest grain yield compared to other treatments. Nayak et al., (2003) revealed weed control treatments significantly decreased dry weight of weeds compared to weedy control. Among herbicidal treatments 2, 4-D and metsulfuron-methyl alone and their combinations showed their superiority over Isoproturon alone and combination of Isoproturon with Metsulfuron-methyl. Yadav et al., (2009) found tank mix or sequential application of sulfosulfuron with carfentrazone being at par reduced density and dry weight of $P$. minor similar to sulfosulfuron alone. Hence, carfentrazone was found compatible with sulfosulfuron as tank mixture against complex weed flora in wheat with no loss of herbicidal efficacy. Jat et al., (2007) found that metsulfuron-methyl alone and in combination with clodinafop, fenoxaprop and sulfosulfuron provide excellent control of BLWs. Sulfosulfuron alone controlled both grassy and BLWs but its efficacy against grasses was lower than clodinafop and fenoxaprop and against BLWs than metsulfuron. Sequential application of clodinafop $f b$ metsulfuron and fenoxaprop $f b$ metsulfuron efficiently controlled complex weed flora and produced maximum grain yield and minimum weed population. Kaur et al., (2007) reported new alternative post emergence herbicides i.e. pinoxaden, sulfosulfuron+metsulfuron, mesosulfuron+ iodosulfuron and trifluralin as pre emergence herbicides were found significantly superior to sulfosulfuron and clodinafop for controlling isoproturon resistant $P$. minor. Brar and Walia (2009) recorded significant reduction in population of Phallaris minor as well as broad leaf weeds and increased grain yield of wheat were observed with post 
emergence application of clodinafop $60 \mathrm{~g} / \mathrm{ha}$ followed by $2,4-\mathrm{D} 0.5 \mathrm{~kg} / \mathrm{ha}$ and metsulfuron + iodosulfuron $12 \mathrm{~g} / \mathrm{ha}$ than clodinafop 60 $\mathrm{g} / \mathrm{ha}$ alone and control. Among weed control practices sulfosulfuron $25 \mathrm{~g} / \mathrm{ha}$ recorded highest yield of wheat. Similarly, Singh et al., (1999) reported improved control of hard weed Canada thistle ( $C$. arvense) with tank mix application of herbicides. Paighan et al., (2013) observed among chemical treatments, application of metsulfuron-methyl $4 \mathrm{~g} / \mathrm{ha}$ gave significantly higher growth and yield attributes of wheat.

Amanpreet and Walia (2010) revealed tall doses of Atlantis 3.6 WDG (metsulfuron + iodosulfuron) i.e. $12 \mathrm{~g}, 18 \mathrm{~g}$, and $24 \mathrm{~g} / \mathrm{ha}$ were at par with respect to yield of wheat, irrespective of variable soil moisture levels present at the time of their application and gave an effective killing of weeds resulting in $100 \%$ reduction of weeds dry matter compared to unsprayed control. Herbicide applied to wheat showed no adverse effect on germination and growth of succeeding kharif crops including summer moong, cotton, okra and sesbania. Walia et al., (2010) evaluated the performance of new herbicide mixture AEF 04-6340-8\% + DIC 1468-14\%-22\% EC (fenoxaprop-p-ethyl + metrbuzin) for control of grassy and broad leaf weeds. Application of this herbicide at 1.25 and 1.5 liter/ha of commercial product provided effective control of $P$. minor and BLWs of wheat crop and were found statistically at par with Atlantis (metsulfuron-methyl + iodosulfuronmethyl) 3.6 WDG $400 \mathrm{~g} / \mathrm{ha}$ of commercial product with respect to dry matter accumulation by Phalaris minor and BLWs. Yasin et al., (2010) reported fenoxaprop-pethyl (Puma Super-75 EW) at $45 \mathrm{~g}$ a.i./ha produced relatively less weed biomass and grain yield (4.2 t/ha) $f b$ fenoxaprop-p-ethyl (Chinlima-6.9 EW) at $85 \mathrm{~g}$ a.i./ha, which was statistically at par with fenoxaprop-p-ethyl (Gramicide-6.9 EW) at $85 \mathrm{~g}$ a.i./ha. Singh et al., (2011) reported better control of $R$. spinosus (92\%) with metsulfuron + carfentrazone tank mixture compared to sole application of either metsulfuron $(85 \%)$ or carfentrazone (78\%). This mixture was better than 2, 4-D formulations as none of the 2, 4-D formulations was effective against $R$. spinosus.

\section{Effect of surfactant on efficiency of herbicides}

Surfactants are used as additives to herbicidal sprays to enhance effect of herbicides on target species. Herbicide spray containing surfactants produce smaller droplets, which spread more uniformly on the plant surface, improve wetting of leaves and spreading of on leaf by lowering surface tension. Most of the leaf surface covered with waxes; surfactants dissolve the circular waxes and enhance foliar retention and penetration of herbicide. They also reduce rate of evaporation and thereby increase herbicide uptake.

Glyphosate providing only $14 \%$ control of Richardia brasiliensis, tank mix application of 2,4-D increased the efficiency to $83 \%$ and addition of surfactant increased mortality by 96-100\% (Sharma and Singh, 2001). Tank mixing of non-ionic and organ silicone surfactants with glyphosate decreased surface tension and contact angle and disrupted or dissolved the waxy layer present at leaf surface to allow greater penetration of glyphosate. Sharma and Singh (1999) assess the effect of metsulfuron-methyl [metsulfuron] (MSM; at 1 and $4 \mathrm{~g} / \mathrm{ha}$ ) alone and in combination with 2, 4-D at 250 and $500 \mathrm{~g} / \mathrm{ha}$ and surfactant (Triton) at $0.1 \%$ on non grassy weeds in wheat cv. UP 2338. Results revealed WCE of MSM at $4 \mathrm{~g} / \mathrm{ha}$ applied alone was similar to MSM at $2 \mathrm{~g} / \mathrm{ha}$ applied with surfactant. Ready mix formulation of MSM+2,4-D at 2+250 g/ha + surfactant had weed control efficacy similar 
to ready mix formulation of $\mathrm{MSM}+2,4-\mathrm{D}$ at $2.0+500 \mathrm{~g} / \mathrm{ha}+$ surfactant or MSM+2,4-D at $4.0+500 \mathrm{~g} / \mathrm{ha}$. MSM alone was relatively better than 2,4-D applied alone. Application of ready mix formulation of MSM applied alone or in combination with 2,4-D and surfactant, being at per among them, had significantly more grain yield compare to application of 2,4-D alone at $500 \mathrm{~g} / \mathrm{ha}$ ethyl ester or sodium salt. Saini and Angiras (2000) determined the optimum rate of sulfosulfuron $(15,22,30,37.5 \mathrm{~g}$ a.i. /ha) for controlling weeds in rained wheat (Triticum aestivum) cv. Surbhi.

Table.1 Major weeds in different wheat growing zones in India

\begin{tabular}{|c|c|c|}
\hline S.No. & Zone & Weed species mostly infesting \\
\hline 1. & $\begin{array}{l}\text { NHZ [J\&K (except } \\
\text { Jammu and Kathua); } \\
\text { H.P. (except Una and } \\
\text { Paonta Valley); } \\
\text { Uttaranchal (except } \\
\text { Tarai area); Sikkim and } \\
\text { hills of West Bengal and } \\
\text { N.E. States] }\end{array}$ & $\begin{array}{l}\text { Anagallis arvensis L., Avena fatua L., Avena } \\
\text { ludoviciana Dur., Capsella bursa-pastoris (L.) } \\
\text { Medik., Chenopodium album L., Convolvulus } \\
\text { arvensis L., Coronopus didymus L., Fumaria } \\
\text { parviflora Lamk., Juncus bufonius L., Lathyrus } \\
\text { aphaca L., Lolium temulentum L., Medicago } \\
\text { denticulata L., Melilotus alba Lamk., Phalaris } \\
\text { minor Retz., Poa annua L., Polygonum nepalense } \\
\text { Meissn., Ranunculus spp., Sorghum halepense (L.) } \\
\text { Pers., Stellaria media (L.) Vallars, Veronica persica } \\
\text { Poir., Vicia sativa L. }\end{array}$ \\
\hline 2. & $\begin{array}{l}\text { NWPZ [Punjab, } \\
\text { Haryana, Delhi, } \\
\text { Rajasthan (except Kota } \\
\text { and Udaipur divisions) } \\
\text { and Western UP (except } \\
\text { Jhansi division), parts of } \\
\text { J\&K (Jammu and } \\
\text { Kathua distt.) and parts } \\
\text { of HP (Una distt. and } \\
\text { Paonta valley) and } \\
\text { Uttaranchal (Tarai } \\
\text { region)] }\end{array}$ & $\begin{array}{l}\text { Alhagi pseudoalhagi (Beib.) Desv., Anagallis } \\
\text { arvensis L., Argemone mexicana L., Avena fatua L., } \\
\text { Avena ludoviciana Dur., Asphodelus tenuifolius } \\
\text { Cav., Carthamus oxycantha Beib, Chenopodium } \\
\text { album L., Chenopodium murale L., Convolvulus } \\
\text { arvensis L., Coronopus didymus L., Circium arvense } \\
\text { L., Daucus carota L., Euphorbia helioscopia L., } \\
\text { Fumaria } \\
\text { parviflora Lamk., Lathyrus aphaca L., Malva } \\
\text { neglecta, Malva parviflora, Medicago denticulata } \\
\text { Willd, Melilotus alba Lamk., Melilotus indica All., } \\
\text { Phalaris minor Retz., Poa annua L., Polygonum } \\
\text { plebejum R. Br., Polypogon monsplensis (L.) Desf., } \\
\text { Rumex dentatus L., Solanum nigrum, Spergula } \\
\text { arvensis L., Stellaria media (L.) Vallars, Trigonella } \\
\text { incise Benth., Trigonella polycerata, Veronica } \\
\text { agrestis L., Vicia sativa L., Vicia hirsute Koch., }\end{array}$ \\
\hline 3. & $\begin{array}{l}\text { NEPZ (Eastern UP, } \\
\text { Bihar, Jharkhand, } \\
\text { Orissa, West Bengal, } \\
\text { Assam and plains of } \\
\text { N.E. States) }\end{array}$ & $\begin{array}{l}\text { Ageratum conyzoides L., Alternanthera sessilis (L.), } \\
\text { Anagallis arvensis L., Argemone mexicana L., } \\
\text { Asphodelus tenuifolius Cav., Avena fatua L., } \\
\text { Brachiaria mutica, Brachiaria ramose, Cannabis } \\
\text { sativa } \mathrm{L} ., \text { Celosia argentea } \mathrm{L} ., \text { Chenopodium album } \\
\text { L., Chenopodium } \\
\text { ficifolium, Chenopodium murale L., Cirsium arvense }\end{array}$ \\
\hline
\end{tabular}




\begin{tabular}{|c|c|c|}
\hline & & $\begin{array}{l}\text { (L.), Commelina benghalensis L., Convolvulus } \\
\text { arvensis L., Coronopus didymus (L.), Cyanotis } \\
\text { cuculata, Cynodon dactylon Pers., Cyperus iria L., } \\
\text { Cyperus rotundus L., Desmodium triflorum (L.) } \\
\text { DC., Digitaria ciliaris (Retz) Koel., Digitaria } \\
\text { sanguinalis (L.) Scop., Drymaria vilosa, } \\
\text { Echinochloa colona (L.) Link, Eclipta alba, Eclipta } \\
\text { prostrate L., Eleusine indica Gaerts., Eragrostis } \\
\text { ferroginia Beauv., Euphorbia dracunculoides, } \\
\text { Fibristylis miliacea, Fumaria indica Pugsley, } \\
\text { Fumaria parviflora, Galinsoga parviflora Cav., } \\
\text { Gnaphalium pensylvanicunm Willd., Gnaphalium } \\
\text { purpureum, Grangea maderaspatana (L.) Poir., } \\
\text { Lathyrus aphaca L., Lathyrus sativa L., Leucas } \\
\text { aspera, Ludwigia perennis, Medicago denticulata, } \\
\text { Melilotus alba Lamk., Melilotus indica All., Mimosa } \\
\text { pudica L., Murdannia nudiflora(L.) Brenan, Oxallis } \\
\text { carniculata L., Panicum repens L., Parthenium } \\
\text { hysterophorus L., Paspalum scorbiculatam L., } \\
\text { Phalaris minor Retz., Physalis minima, Poa annua } \\
\text { L., Polygonum barbatum L., Polygonum erectum, } \\
\text { Polygonum plebejium R. Br., Polypogon } \\
\text { monsplensis (L.) Desf., Rumex dentatus L., Scirpus } \\
\text { articulates, Solanum nigrum, Spergula arvensis L., } \\
\text { Sporoboles indicus (L.) R.Br. Var.diader, Stellaria } \\
\text { media (L.) Vallars, Vicia hirsute Koch., Vicia sativa, } \\
\text { Xanthium stumarium, }\end{array}$ \\
\hline 4. & $\begin{array}{l}\text { CZ (Madhya Pradesh, } \\
\text { Chhattisgarh, Gujarat, } \\
\text { Kota and Udaipur } \\
\text { divisions of Rajasthan } \\
\text { and Jhansi division of } \\
\text { Uttar Pradesh) }\end{array}$ & $\begin{array}{l}\text { Achyranthus aspera L., Alhagi pseudolhagi (Beib.) } \\
\text { Desv., Amarantus viridis L., Anagallis arvensis } \\
\text { L., Argemone maxicana L., Asphodelus tenuifolius } \\
\text { Cav., Avena fatua L., Avena ludoviciana Dur., } \\
\text { Boerhaavia spp., Brassica kaber, Brassica sinensis, } \\
\text { Chenopodium album L., Chenopodium murale L., } \\
\text { Chrozophera perviflora L., Cichorium intybus L., } \\
\text { Cirsium arvense L., Convolvulus arvensis L., } \\
\text { Cynodon dactylon Pers., Cyperus iria L., Cyperus } \\
\text { rotundus L., Dactyloctenium aegyptium L., Digera } \\
\text { arvensis, Digitaria adscendens, Dinebra retroflexa } \\
\text { (Vahl.) Panzer, Echinochloa colona (L.) Link, } \\
\text { Eclipta alba, Eleusine indica Gaerts., Eragrostis } \\
\text { cilienensis (All) Link., Eragrostis major, Euphorbia } \\
\text { geniculata Ortega, Euphorbia hirta L., Fumaria } \\
\text { parviflora, Lathyrus aphaca L., Launaea } \\
\text { asplenifolia (willd.) Hook. f., Medicago denticulata, } \\
\text { Melilotus alba lamk., Melilotus indica All., } \\
\text { Melilotus parviflora, Melilotus sativa, Melotropicum }\end{array}$ \\
\hline
\end{tabular}




\begin{tabular}{|c|c|c|}
\hline & & $\begin{array}{l}\text { indicum, Parthenium hysterophorus L., Phalaris } \\
\text { minor Retz., Phyllanthus fraternus Webster., } \\
\text { Physalis minima, Ranunculus acutus, Rumex } \\
\text { dentatus L., Solanum nigrum, Sonchus asper (L.) } \\
\text { Hill., Spergula arvensis L., Sphaeranthus indicus L., } \\
\text { Stellaria media (L.) Scop., Suaeda maritime (L.) } \\
\text { Dum., Tephrosia pururea, Tribulus terrestris L., } \\
\text { Tridax procumbens L., Vicia hirsute Koch., Vicia } \\
\text { sativa, Xanthium strumarium, }\end{array}$ \\
\hline 5. & $\begin{array}{l}\text { PZ (Maharashtra, } \\
\text { Karnataka, Andhra } \\
\text { Pradesh, Goa, plains of } \\
\text { Tamil Nadu) }\end{array}$ & $\begin{array}{l}\text { Alternanthera sessilis L., Amarantus graceizans L., } \\
\text { Anagallis arvensis L., Argemone mexicana L., } \\
\text { Asphodelus tenuifolius Cav., Avena fatua L., Bidens } \\
\text { pilosa, Brachiaria eruciformis L., Brassica arvensis } \\
\text { L., Cassia spp., Celosia argentia, Chenopodium } \\
\text { album L., Commelina benghalensis L., Convolvulus } \\
\text { arvensis L., Chrozophera perviflora L., Cynodon } \\
\text { dactylon Pers., Cyperus rotundus L., Digera } \\
\text { arvensis, Digitaria adscendens, Dinebra retroflexa, } \\
\text { Echinochloa colona (L.) Link, Euphorbia hirta L., } \\
\text { Lactuca runcinata DC., Lagascea mollis, Leucas } \\
\text { aspera, Melilotus alba Lamk., Parthenium } \\
\text { hysterophorus L., Phyllanthus spp., Portulaca } \\
\text { oleracea L., Physalis minima, Setaria verticillata, } \\
\text { Sonchus wightianus DC., Spergula arvensis L., } \\
\text { Sphaeranthus senegalensis DC., Trianthema } \\
\text { portulacastrum, Zizipus jujube Lamk. }\end{array}$ \\
\hline
\end{tabular}

The dominant weeds in the experimental field were Avena fatua, Phalaris minor, Lolium temulentum, Coronopus didymus, Anagallis arvensis, Stellaria madia and Vicia sp. Sulfosulfuron at $30 \mathrm{~g}$ a.i. /ha was par with sulfosulfuron $30 \mathrm{~g}$ a.i./ha + surfactant and sulfosulfuron at $37.5 \mathrm{~g}$ a.i./ha or without surfactant in significantly reducing weed dry weight and increasing crop yield. A field experiment was conducted to assess effect of Metsulfuron-methyl alone and in combination with 2,4-D. Application of metsulfuron-methyl alone was relatively better than 2,4-D applied alone. Application of ready mix formulation of metsulfuron-methyl alone or in combination with 2,4-D and surfactant, being at par among them had significantly more yield compare to application of 2,4-D alone (Singh et al., 2002). Singh (2006) conducted an experiment to evaluate effect of growth stage and surfactant on the efficacy of sulfosulfuron against some grass and BLWs. Effect of sulfosulfuron was more when applied at 2 to 3 leaf stage compared to 4 to 6 leaf stage, particularly for BLWs. Surfactants significantly increase the herbicidal activity of sulfosulfuron; the effect was more conspicuous on broad leaf weeds.

In conclusion, weeds pose severe competition with the crops for various growth resources. Besides reduction in grain yield, weeds also reduce the quality of produce and act as alternate host for disease causing organisms and insect-pests. Hence, various weed management practices need to be integrated in an appropriate manner during critical period of crop-weed competition. Research on herbicide mixture, post-emergence herbicides in pulses and oilseed, management of parasitic weeds, weed competitive crop cultivars with acceptable yield 
potential, weed management in changing climate scenario and conservation agriculture, effect of herbicides on soil microorganisms need to be strengthened. Considering several advantages of using herbicide resistant crop, it is worthwhile exploring their possible use under Indian conditions.

\section{References}

Aldrich, R.J. 1987. Predicting crop yield reduction. Weed Techn., 1(3): 199-206.

Amanpreet and Walia, U.S. 2010. Bio-efficacy and persistence of Atlantis (metsulfuron + iodosulfuron) applied in wheat as influenced by soil moisture levels and soil types. National symposium on Integrated Weed Management in the era of climate change. NASC, New Delhi. 21-22 August, 2010. Indian Society of Weed Science.

Bohra, J.S. and Kumar, R. 2015. Effect of crop establishment methods on productivity, profitability and energetics of rice (Oryza sativa)-wheat (Triticum aestivum) system. Indian J. Agric. Sci., 85 (2): 217-223.

Brar, A.S. and Walia, U.S.2007. Studies on composition of weed flora of wheat (Triticum aestivum L.) in relation to different tillage practices under ricewheat cropping system. Indian J. Weed Sci., 39 (3 \& 4): 190-196.

Brar, A.S. and Walia, U.S.2009. Weed dynamics and wheat (Triticum aestivum L.) productivity as influenced by planting techniques and weed control practices. Indian J. Weed Sci., 41 (3 \& 4): 161-166.

Chhokar, R.S., Sharma, R.K. and Sharma, I. 2012. Weed management strategies in wheat-A review. J. Wheat Res., 4(2): 121.

Chopra, N. and Chopra, N.K. 2005. Bioefficacy of fenoxaprop, clodinafop, metribuzin alone and in combination against weeds in wheat and their residual effect on succeeding crops. Indian J. Weed Sci., 37: 163-166.

Chopra, N.K. and Chopra, N. 2010. Evaluation of tillage system and herbicide on wheat performance under rice-wheat cropping system. Indian J. Agron., 55:304-307.

Chopra, N.K., Chopra, N. and Singh, H. 2008. Bio-efficacy of herbicide mixtures against complex weed flora in wheat (Triticum aestivum). Indian J. Agron., 53(1): 62-65.

Cudeny, D.W., Jordan, L.S. and Hall, A.E. 1991. Effect of wild oat (Avena fatua) infestation on light interception and growth rate of wheat (Triticum aestivum). Weed Sci., 39 (2): 175-179.

Garg, R., Punia, S.S., Yadav, D.B. and Malik, Y.P. 2007. Weed flora of wheat in Panipat district of Haryana. Haryana $J$. Agron., 23 (1/2): 120-121.

Gautam, K.C., Mani, V.S. and Das, B.1975. Note on economizing nitrogenous fertilization in wheat through chemical weed control. Indian J. Weed Sci. 6: 121123.

Godel, G.L. 1995. Relation between rate of seedling and yield of cereal crops in combination with weeds. Scientific Agric.16: 165-168.

Hooda, V.S., Dhukia R.S., Malik R.K., Yadav A., Kumari R. and Singh, S. 2007. Influence of irrigation and metsulfuronmethyl on growth, yield attributes and yield of wheat (Triticum aestivum L.). Indian J. Weed Sci., 39 (1\&2): 123-125.

Jalis, A. and Brohi 1978. A composition study of weed infested and weed free wheat wheat field. J. Agri. Res. Pakistan, 16 (2): 155-163.

Jat, J.K., Punia, S.S. and Malik, R.K. 2007.Efficacy of herbicide mixture and sequential applications against different weed in wheat (Triticum aestivum L.). Indian J. Weed Sci., 39 (1 \& 2): 132-134.

Jeet, S., Kler, D.S., Kumar, R. and Kumari, A. 2010a. Response of seed rates and nitrogen levels in relation to crop residue management on microenvironment of bed planted soybean (Glycine $\max$ )-wheat (Triticum aestivum) system. Environ. Ecol., 28 (3):1571-1576.

Jeet, S., Saini, K.S., Kumar, R. and Kumari, A. 2010b. Effect of seed rates and nitrogen levels in relation to crop residue 
management on growth and yield of soybean and wheat in bed planted soybean (Glycine max)-wheat (Triticum aestivum) system. Environ. Ecol., 28 (3):1553-1557.

Jeet, S., Singh, D., Kumar, R. and Kumari, A. 2010c. Yield and physico-chemical properties of soil as affected by seeding rates and nitrogen levels in relation to crop residue management on bed planted soybean (Glycine max)-wheat (Triticum aestivum) system. Environ. Ecol., 28 (3B):2063-2067.

Kaur, M., Walia, U.S. and Sindhu, V.K.2007. Bioefficacy of herbicides for the control of isoproturon resistant Phalaris minor Retz. and their residual effect on succeeding crops. Indian J. Weed Sci., 39 (1 \& 2): 126-128.

Kumar, S., Dwivedi, S.K., Kumar, R., Mishra, J.S., Singh, S.K., Prakash, V., Rao, K.K. and Bhatt, B.P. 2017.Productivity and energy use efficiency of wheat (Triticum aestivum) genotypes under different tillage options in rainfed ecosystem of middle Indo-Gangetic Plains. Indian $J$. Agron., 62 (1): In Press.

Kundra, H.C. and Singh, R. 1985. Effects of weed control treatments on utilization of nutrient elements by wheat in association with weeds. Abst. Ann. Conf. Indian Soc. Weed Sci., 35 (6): 206.

Kurchania, S.P., Bhalla, C.S. and Paradkar, N.R.2000. Bioefficacy of metsulfuronmethyl and 2, 4-D combination for broadleaf weed control in wheat. Indian J. Weed Sci., 32 (1/2): 67-69.

Malik, R.S., Balyan, R.S., Malik, R.K. and Banga, R.S.2001.Efficacy of new herbicides with and without surfactant on weeds in wheat. Indian J. Weed Sci., 33: 59-62.

Malik, R.S., Yadav, A. and Malik, R.K. 2008. Evaluation of different herbicides against broadleaf weeds in wheat and their residual effect on sorghum. Indian $J$. Weed Sci., 40: 37-40.

Martin, M.P.L.D. and Field, R.J.C. 1988. Influence of time of emergence of wild oat on competition with wheat. Weed Res., 28 (2): 111-116.

Maurya, P., Kumar, V., Maurya, K.K., Kumawat, N., Kumar, R. and Yadav, M.P. 2014. Effect of potassium application on growth and yield of wheat varieties. The Bioscan, 9 (4): 1371-1373.

Mishra, A. and Mani, V.S. 1968. The herbicidal and stimulatory effect of combination of 2,4-d and urea in wheat combination. Ninth British Weed Control Conference, pp. 804-808.

Mustari, S., Bari, M.N., Islam, M.R. and Karim, A.J.M.S. 2014.Evaluation of selected herbicides on weed control efficiency and yield of wheat. J. Sci. Found.12 (2): 2733.

Nalawaja, J.D. 1968. Wheat yield losses the year following weed infestation. $N$. Contr. Weed Contr, Conf. Res. Rept., 21: 145.

Nayak, S., Rawat, A.K. and Sharma, R.S. 2003. Effect of Metsulfuron-methyl and 2, 4-D alone and in combination for control of broad leaf weeds in irrigated wheat. JNKV Res. J., 37 (1): 104-106.

Paighan, V.B., Gore, A.K. and Chavan, A.S.2013. Effect of new herbicides on growth and yield of wheat. Indian $J$. Weed Sci. 45(4): 291-293.

Pandey, I.B., Mishra, S.S., Singh, H. and Prasad, N. 2000. Nutrient uptake by wheat (Triticum aestivum) and associated weeds as influenced by fertilizer levels and weed management. Indian J. Weed Sci.32: 31-34.

Pandey, J. and Singh, U.P. 1983. Nutrients removal by wheat and weeds as affected by metoxuron application. Indian J. Weed Sci., 15: 29-37.

Paswan, A.K., Kumar, R., Kumar, P. and Singh, R.K. 2012. Influence of metsulfuronmethyl and carfentrazone-ethyl either alone or in combination on weed flora, crop growth and yield in wheat (Triticum aestivum). Madras Agric. J., 99 (79):560-562.

Patel, M.V., Patel, B., Patel, B.D. and Meisuriya, M.I. 2005. Evaluation of carfentrazone-ethyl for weed control in 
wheat. Proc. National biennial conference, ISWS, PAU, Ludhiana. April 6-9 pp. 36-38.

Punia, S.S., Kamboj, B., Sharma, S.D., Yadav, A. and Sangwan, N. 2006. Evaluation of carfentrazone-ethyl against Convolvulus arvensis and Malwa parviflora L. in wheat. Indian J. Weed Sci., 38 (1 \& 2): 58.

Reeves, T.C.C.1976. Effect of annual rye grass (Lolium rigidum) on yield of wheat. Weed Res., 16: 57-63.

Sage, R.E. and Pearcy, R.W. 1987. The nitrogen use efficiency of $\mathrm{C} 3$ and $\mathrm{C} 4$ plant and leaf nitrogen growth and biomass partitioning in Chenopodium album (L.). Plant Physio., 84 (3): 954-956.

Saini, J.P. and Angiras, N.N. 2000. Standardization of dose of sulfosulfuron (MON 37503) in controlling weeds of rainfed wheat (Triticum aestivum) under mid-hill condition of Himachal Pradesh. Indian J. Agron., 50(1): 41-43.

Sardana, V., Walia, U.S. and Mahajan, G. 2001. Management of broad leaf weeds in wheat (Triticum aestivum L.). Indian J. Weed Sci., 33: 113-115.

Sharma, R. and Ahuja, S.S.2001. Bioefficacy of chlorsulfuron, metsulfuron and metribuzin alone and in combinations for weed control in wheat (Triticum aestivum L.). Indian J. Weed Sci., 33 (3/4): 112115.

Sharma, S.D. and Singh, M.1999. Effect of two adjuvant types on the distribution of ${ }^{14} \mathrm{C}$ glyphosate applied to model weed species. Brighton crop protection conference-weeds. pp. 729-734.

Sharma, S.D. and Singh, M.2001.Surfactant increase toxicity of glyphosate and 2, 4-D to Brazil pusley. Hort. Sci., 36: 726-728.

Sidhu, D., Walia, U.S. and Brar, L.S. 2000. Herbicidal control of Rumex spinosus (Kandiali palak) in wheat (Triticum aestivum L.). Indian J. Weed Sci., 32: 156-159.

Singh, A.K., Kumar, R., Singh, A.K., Kumari, A. 2011a. Bio-efficacy of sulfosulfuron on weed flora and irrigated wheat
(Triticum aestivum L.) yield. Environ. Ecol., 29 (2A):834-838.

Singh, A.K., Kumar, R., Singh, A.K., Singh, N.K. and Kumari, A. 2011b. Performance of sulfosulfuron against weeds in irrigated wheat (Triticum aestivum L.). Environ. Ecol., 29 (2A):831-833.

Singh, B.B. and Singh, S.B. 1979. Effect of herbicides on yield and chemical composition of wheat grain. Indian Soc. Weed Sci. Conf. Prabhani, p. 21.

Singh, G., Singh, M. and Singh, V.P.2002.Effect of metsulfuron-methyl alone and in combination with 2,4-D and surfactant on non-grassy weed and wheat yield. Indian J. Weed Sci., 34(3 \& 4): 175-177.

Singh, H.G. 1967. Effect of 2, 4-D on crop weed competition in wheat. Indian $J$. Agron., 12 (1): 25-30.

Singh, J. and Singh, K.P. 2005. Effect of organic manures and herbicides on yield and yield attributing character of wheat. Indian J. Agron., 50(4): 289-291.

Singh, P. and Ali, M. 2004. Efficacy of metsulfuron-methyl on weeds in wheat and its residual effect on succding soybean crop grown on vertisols of Rajasthan. Indian J. Weed Sci., 36 (1/2): 34-37.

Singh, R.D. and Ghosh, A.K. 1992. Evaluation of herbicides for control of wild oat (Avena ludoviciana) in wheat (Triticum species). Indian J. Agron. 37: 327-331

Singh, R.K., Singh, D.K. and Singh, R.P. 1997. Weed crop competition in wheat as affected by different weed species. Indian J. Weed Sci. 29: 199.

Singh, R.K., Singh, S.R.K. and Gautam, U.S. 2013. Weed Control Efficiency of Herbicides in Irrigated Wheat (Triticum aestivum). Indian Res. J. Ext. Edu., 13 (1): 126-128.

Singh, S. 2006. Effect of growth stage and surfactant on the efficacy of sulfosulfuron against some grass and broad leaf weeds. Haryana J. Agron., 22(2): 170-173.

Singh, S., Kirkwood, R.C. and Marshall, G. 1999. Biology and control of Phalaris 
minor Retz. (littleseed canarygrass) in wheat. Crop Protec. 18: 1-16.

Singh, S., Punia, S.S., Yadav, A. and Hooda, V.S.2011.Evaluation of Carfentrazoneethyl+Metsulfuronmethyl against Broadleaf Weeds of Wheat. Indian $J$. Weed Sci., 43: 12-22.

Singh, S., Yadav, R.A., Kumar, R. and Verma, S.S. 2014. Influence of herbicides against weeds associated with wheat (Triticum aestivum L.). Bioinfolet, 11 (3B): 855857.

Thomas, C.G. and Yaduraju, N.T. 1999. Competitive effects of wild oats (Avena steils sp. ludoviciana (Durr.) Nym. On light interception and growth of wheat. Indian J. Weed Sci., 31: 56-59.

Tosh, G.C. and Mishra, A.1977. Studies on the effect of herbicides on weed control and yield of wheat in irrigated upland. Pesticides, 9 (7): 31-32.

Vaishya, R.D. and Kumar, P. 1993. Effect of methods of isoproturon application on weeds in wheat. Indian J. Weed Sci., 25: 115-117.

Vashisht, R., Sangwan, N. Solanki, Y.P.S. 2008. Weed flora of wheat in Jhajjar district of Haryana in three different crop rotations. Res. Crops, 9(3): 563-565.

Verma, A.K. and Pandey, J. 2004. Effect of isoproturon tank mix with metsulfuron and 2, 4-D on weed and yield of wheat (Triticum aestivum). Indian J. Agron., 49: 114-116.

Verma, A.K. and Pandey, J. 2002. Effect of atrazine, metribuzin, sulfosulfuron and tralkoxydim on weeds and wheat yield. Indian J. Agron., 47: 72-76.
Walia, U.S. and Singh, M. 2007.Influence of application and stage of sulfonyl urea herbicides for the control of Phalaris minor in wheat. Indian J. Weed Sci., 37 (3 \& 4): 184-187.

Walia, U.S., Kaur, T., Kaur, R. and Sumbria, R. 2010. Performance of new herbicide (AEF 04-6340-8\% + DIC 1468-14\%-22\% EC) for the control of grassy and broad leaf weeds in wheat. National symposium on Integrated Weed Management in the era of climate change. NASC, New Delhi. 21-22 August, 2010. Indian Society of Weed Science. weeds and cereal crops. Canadian J. Res., 10: 77-94.

Witkowsski and Halling, B. P. 1989. Plant Physio., 90: 12-39.

Yadav, D. B., Yadav, A. Singh, S. and Lal, R. 2009. Compatibility of fenoxaprop-Pethyl with carfentrazone-ethyl metsulfuron-methyl and 2, 4-D for controlling complex weeds of wheat. Indian J. Weed Sci., 41(3/4): 157-160.

Yadav, L., Sharma, J., Singh, A.K., Kumar, R., Meena, R.N. and Choudhary, H.R. 2013. Efficacy of 2, 4-D herbicide application on growth, yield and spike deformities in late sown wheat varieties in Eastern Uttar Pradesh. Madras Agric. J., 100 (1-3):135138.

Yasin, M., Tanveer, A., Iqbal, Z. and Ali, A. 2010. Effect of Herbicides on Narrow Leaved Weeds and Yield of Wheat (Triticum aestivum L.). International J. Bio., Biomole., Agril., Food Biotechn. Engi., 4 (8): 619-621.

Zimdahl, R.L. 2013. Fundamentals of Weed Science, fourth ed. Academic Press.

\section{How to cite this article:}

Ajit Kumar Paswan, Devendra Mandal, Narendra Kumawat, Jeetendra Kumar, Rakesh Kumar, Anil Kumar Singh and Anil Kumar. 2017. Efficacy of Separate and Premix Formulation of MetsulfuronMethyl and Carfentrazone-Ethyl on Weeds in Wheat: A Review. Int.J.Curr.Microbiol.App.Sci. 6(7): 2439-2453. doi: https://doi.org/10.20546/ijcmas.2017.607.289 